MOVERS

Felipe Pereira, distinguished professor, School of Energy Resources and Department of Mathematics, University of Wyoming, Laramie

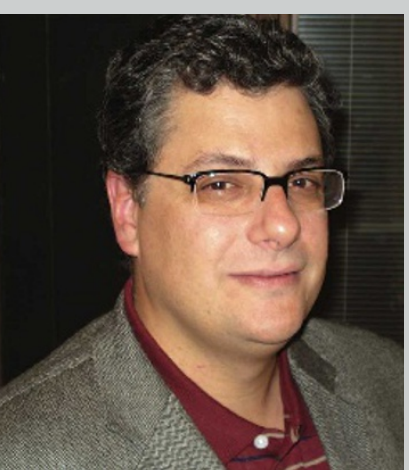

1999-2007: Professor, computational and applied mathematics, State University of Rio de Janeiro, Brazil 1997-99: Visiting professor, State University of Rio de Janeiro, Brazil 1997-99: Associate researcher, National Laboratory for Scientific Computing, Petrópolis, Brazil

Felipe Pereira made his mark in the world of applied mathematics by modelling the flow of oil in underground reservoirs - information needed for the efficient extraction of this precious resource. Although he will continue working on such models, his latest research challenge is a sign of changing times. As one of the distinguished faculty members at the new School of Energy Resources at the University of Wyoming in Laramie, Pereira will apply those same skills to determine how best to inject and sequester carbon dioxide beneath Earth's surface and so help reduce its contribution to climate change.

Pereira studied physics at the Federal University of Minas Gerais in his native Brazil. As a graduate student under Michael O'Carroll, a US mathematician working at the interface of quantum field theory and statistical mechanics, Pereira became increasingly interested in applied mathematics. Impressed when Pereira quickly solved a problem that had stumped him, O'Carroll directed his student to James Glimm and the maths PhD programme at New York University.

There in 1985, with funding from the Brazilian government, Pereira began working on simulations relating to gas dynamics and oil reservoirs. Until this time Pereira had never used a computer, so when he followed Glimm to the State University of New York at Stony Brook, he set about honing his computing skills.

Moving to Purdue University in West Lafayette, Indiana, in 1994, Pereira worked with Jim Douglas, the top oil-reservoir modelling and simulation mathematician of the time. Douglas says that Pereira provided key information about underground flows of oil despite a lack of detailed data from studies probing beneath Earth's surface, which often were not feasible. After three years, Pereira returned to Brazil, first at the National Laboratory for Scientific Computing in Petrópolis and then as a faculty member at State University of Rio de Janeiro.

As he takes on his new position in Wyoming, Pereira says that applied mathematics has a critical role to play in the energy field because oil will still be needed to supply our immediate energy needs, and sequestering carbon is one way to mitigate the effects of greenhouse-gas emissions. Douglas agrees, noting that applied mathematics remains a very active field as it offers a way to solve such real-world problems.

Virginia Gewin
NETWORKS \& SUPPORT

\section{Neuroscience in the developing world}

How do you teach neuroscience techniques in countries bereft of funding and infrastructure? In Argentina, the education programme of the International Brain Research Organization (IBRO) found a creative answer: crabs.

John Hildebrand, one of the founders of the IBRO's international schools, chose Buenos Aires for a class on neuroethology, the neural basis of natural behaviour. Crabs, which provide good nervous-system models, were abundant. "Students work with little crabs they collect in mud flats near the seashore," says Hildebrand, a neuroscience professor at the University of Arizona, Tucson. "They have no animal-rearing costs. They can work in shirtsleeves and do very beautiful work."

But the three-week course - which attracted students from several Latin American countries - was no seaside outing. During a week each of lectures, fieldwork and experiments, work started early and discussions continued late into the evenings.

The IBRO offers courses in developing countries at four levels from basic lectures introducing neuroscience concepts to courses teaching the latest brain-science techniques and analysis of complex data sets. Students can start on the introductory rung and work on up.

The IBRO uses visiting teams of six or seven scientists. They hold classes in places that have had little interaction with the West, including the Andes, Iran and remote parts of Africa. One challenge is deciding what technology to take with them and use in the host countries. Picking the right model organism, such as the crabs in Argentina, provides a way to bridge the resources gap. They have used insects in Africa and frogs in China.

The course has informed and even altered career paths. It inspired one medical student from Uruguay to switch to neuroscience: a bold move because medicine is a more stable, lucrative profession in Latin America. "Doing what she did was a very, very risky decision," says instructor Martin Giurfa, an Argentinian neuroscience professor now at the University of Toulouse, France. He was gratified when she told him later that she had made the right decision.

In Argentina, the course included discussions of career concerns.

Drawing on his own experience (see Nature 451, 494-496; 2008), Giurfa said that pursuing a scientific career in a developing country is challenging, but can be done: "You just have to fight and fight and fight." Paul Smaglik

\section{POSTDOC JOURNAL}

\section{Role models}

Having postdocs rather than professors as 'role models' may seem a bit odd, but I am fortunate to have several postdoc friends who have been exactly that. They enrich my life by the diversity of their expertise and personalities. One is a cell biologist who plays a Renaissance-era trombone and runs marathons, showing that scientists can maintain a healthy work-life balance. Another is a structural biologist who taught me much about biophysics and pushed me to run farther and faster. Yet another is a virologist who combines motherhood with good science, thanks to efficiency and a positive attitude.

They may not be deans or directors, but nor are they like statues on pedestals. I can relate to them. Their dedication and rigour inspire me more than their awards. Knowing their struggles increases my respect for them, and I hope that I can similarly overcome adversity. Most importantly, they take the time to mentor and to be friends, sharing joys and disappointments alike.

In young labs such as my current one, where most of us are first-time postdocs, peer support is a substitute, to some extent, for mentorship. We are like first-time kayakers navigating expert-level class $\vee$ whitewater. I'm cold and drenched but still paddling. And now it's my turn to serve as a role model as best I can, to try to help others navigate those waters.

Amanda Goh is a postdoctoral fellow in cell biology under the Agency of Science, Technology and Research in Singapore. 